\title{
HYPOPHOSPHATEMIA IN ACUTE \& CHRONIC LIVER DISEASES.
}

\author{
Pradeep. V. Vernekar ${ }^{1}$
}

\section{HOW TO CITE THIS ARTICLE:}

Pradeep. V Vernekar. "Hypophosphatemia in acute \& chronic liver diseases". Journal of Evolution of Medical and Dental Sciences 2013; Vol. 2, Issue 43, October 28; Page: 8372-8378.

\begin{abstract}
Hypophosphatemia has serious metabolic effects that may increase morbidity and mortality in many illnesses. The present study was designed to know the incidence and severity of hypophosphatemia in a cohort of patients with acute and chronic liver diseases.The acute liver disease group comprised of cases in which the liver damage has been induced by type-A and type-B viral hepatitis. The chronic liver disease group comprised of cases in which the liver damage in the form of hepatitis and cirrhosis has been induced by alcohol. All the patients with acute and chronic liver diseases showed significantly lower phosphate levels when compared to the control group. However, significant difference in phosphate levels between the acute and chronic liver disease groups were not observed. Whether frequent monitoring of serum phosphate levels and early treatment of severe hypophosphatemia will alter the prognosis of patients with acute and chronic liver diseases should be determined in further studies.
\end{abstract}

KEY WORDS: Hypophosphatemia ; Acute liver disease; Chronic liver disease;

INTRODUCTION: Hypophosphatemia has serious metabolic effects that may increase morbidity

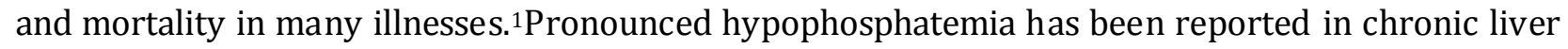
diseases like alcoholic liver disease, viral hepatitis and Reye's syndrome.2,3Abnormal cerebral phosphate metabolism may play a part in chronic hepatic encephalopathy. It has been observed that acute and chronic liver diseases are associated with decreased serum phosphate levels. ${ }^{2,3}$ The similarity of effect of liver failure and hypophosphatemia suggests that phosphate depletion may play an important role in hepatic encephalopathy. The present study was designed to know the incidence and severity of hypophosphatemia in a cohort of patients with acute and chronic liver diseases.

MATERIALS AND METHODS: The study included a cohort of patients admitted to a tertiary care hospital in South India over a reference period of 30 months. The study group included patients with acute liver diseases and chronic liver diseases. These were compared with normal individuals who were admitted for other unrelated minor illnesses. The patients who were admitted for liver abnormalities were divided into acute and chronic types based on detailed clinical history, thorough physical examination and relevant investigations including liver function tests. All patients, i.e. those with diagnosed acute and chronic liver diseases along with the control group underwent these tests as early as they got admitted. All tests were done according to the standard universal test methods. ${ }^{4-}$ 10 Twenty-five patients were recruited into each of these three groups, i.e. patients with acute liver disease, patients with chronic liver disease and control group. In all these 75 patients, phosphorus was estimated according to molybdate UV end point calorimetric single chemistry method.11,12The normal phosphate levels were estimated to be $4-7 \mathrm{mg} / \mathrm{dl}$.

The data analysis was done using T-test. The analysis of data was done by SPSS, If P value is $<0.05$ the test is considered significant. 
RESULTS: The mean ( \pm S.D.) age of the patients with acute liver disease was $33.40( \pm 14.39)$ years. The mean $( \pm$ S.D.) age of the patients with chronic liver disease was $45.84( \pm 13.63)$ years. The mean $( \pm$ S.D.) age of the patients in the control group was $44.56( \pm 14.80)$ years. The age ranged from 17 to 69 years, 17 to 63 years and 16 to 66 years in the patients with acute liver disease, patients with chronic liver disease and control group, respectively. The acute liver disease group comprised of cases wherein the liver damage had been induced by type-A and type-B viral hepatitis. The chronic liver disease group comprised of cases wherein the liver damage in the form of hepatitis and cirrhosis had been induced by alcohol. The control group comprised of apparently healthy persons and those suffering from some minor ailments and who had completely normal liver function tests. The comparison of the various standard liver function tests and phosphate levels between the three groups (age and sex matched) is shown in Table 1. All the 25 patients with acute liver disease showed significantly lower phosphate levels when compared to the control group $(P=0.001)$. Similarly, all the 25 patients with chronic liver disease showed significantly lower phosphate levels when compared to the control group $(\mathrm{P}=0.001)$. The phosphate levels were within the normal range in all the subjects in the control group. However, significant difference in phosphate levels between the acute and chronic liver disease groups was not observed $(\mathrm{P}=0.35)$.

DISCUSSION: Although the phosphate levels were marginally lower in patients with acute liver disease as compared to patients with chronic liver disease, the values were not statistically significant. Similar results have been obtained by other researchers. ${ }^{13-17 H y p o p h o s p h a t e m i a ~ c a n ~}$ occur in various other conditions like hemodialysis, hypothyroidism, volume expansion, starvation, glucose or fructose administration, renal tubular defects, diuretic therapy, insulin administration, saline infusion and hypokalemia. Hypophosphatemia can commonly occur after parental nutrition, which is very common in critically ill patients or after any surgical procedure till patient resumes oral feeding. ${ }^{18,19}$ The first record of hypophosphatemia in acute liver failure induced by paracetamol was made by Dawson et.al.14Hypophosphatemia was noticed in all 12 patients with paracetamol induced liver damage and in more than one-third it was severe $(<0.9 \mathrm{mg} / \mathrm{dl})$. Nanji and Anderson 16 found severe hypophosphatemia in a patient with acute hepatic failure. The absence of other causes of hepatic necrosis combined with an improvement in the clinical state of the patient with the return of phosphate levels towards normal lead them to hypothesize that hypophosphatemia might have been responsible for the acute hepatocellular necrosis. Hypophosphatemia causes depletion of red cell 2,3 diphosphoglycerate which primarily functions in promoting oxygen release from oxyhemoglobin thereby causing hepatic hypoxia. ${ }^{17}$ It has not been proved conclusively that hypophosphatemia per se causes hepatic failure. ${ }^{15}$ The cause of hypophosphatemia in acute viral hepatitis is not clear. In paracetamol poisoning, the drug acts directly on renal tubules, thereby decreasing reabsorption of phosphate.

In chronic liver diseases due to alcoholic cirrhosis, significantly lower levels of serum phosphates were observed in all cases. A host of factors could be responsible for the phosphate depletion in alcoholic cirrhosis. Among the obvious causes could be poor intake, use of antacids, diarrhea and vomiting. Other additional causes can be ethanol per se, magnesium deficiency, alcoholic hypocalcaemia and ketoacidosis. Ethanol inhibits release of Antidiuretic hormone and therefore diminishes reabsorption of water by kidneys. This diuretic effect of ethanol is only 
observed when blood alcohol concentration is raising and is probably negligible in chronic alcoholics.20It has been clearly established that chronic alcoholics may become magnesium deficient. ${ }^{21}$ Phosphaturia, a feature of magnesium deficiency leads to phosphate deficiency. Most patients with severe advanced alcoholism show a low serum calcium concentration. This could result from interference with calcium transport in the gut or mal-absorption. Ketoacidosis may cause phosphate depletion in alcoholics.13,22-24 Since these patients ingest grossly inadequate diets, ketonuria is a rather common finding. Repeated episodes of ketoacidosis may serve to decompose organic phosphate within cells and lead to loss of phosphate in urine. Patients with cirrhosis of liver appear more inclined to develop hypophosphatemia after glucose loads than normal subjects. ${ }^{25}$ This occurs because when phosphate depleted alcoholics are admitted to a hospital acute hypophosphatemia may precipitate metabolic acidosis. The most effective approach to hypophosphatemia is prevention in susceptible condition. Patients on total parenteral nutrition should receive the daily maintenance doses of phosphate amounting to $1000 \mathrm{mg}$ in 24hours with increases as required by the clinical and metabolic states. Alcoholic patients receiving intravenous fluids, particularly those with glucose, should receive phosphate supplements especially if they present with hypophosphatemia. In diabetic ketoacidosis up to $75 \mathrm{mg} / \mathrm{kg}$ of phosphorus per day may be required to restore adequate balance. Dialysis patients who usually have hypophosphatemia may develop iatrogenic hypophosphatemia secondary to dialysis and the use of phosphate binder. In patients requiring prolonged antacid therapy alternative treatment with $\mathrm{H} 2$ blockers should be considered. If this is not feasible phosphate supplementation of $250 \mathrm{mg}$ of phosphate for every $100 \mathrm{ml}$ of antacids should be given.

The present study findings indicate that significant hypophosphatemia is seen in both acute and chronic liver diseases. Whether frequent monitoring of serum phosphate levels and early treatment of severe hypophosphatemia will alter the prognosis of patients with acute and chronic liver diseases should be determined in further studies.

\section{REFERENCES:}

1. Knochel JP. The pathophysiology and clinical characteristics of severe hypophosphatemia. Arch Intern Med 1977;137:203-20.

2. Frank BW, Kern F Jr. Serum inorganic phosphorus during hepatic coma. Arch Intern Med 1962;110:865-71.

3. Carrol JL, Kanter RK. Hypophosphatemia and Reye's syndrome. Crit Care Med 1985;13:480-2.

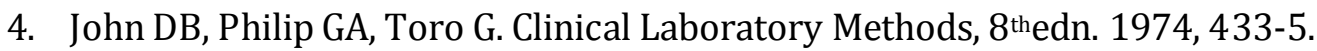

5. Lathe GH, Ruthven CR. Factors affecting the rate of coupling of bilirubin and conjugated bilirubin in the Van De Berg reaction. J ClinPathol 1958;11:155-61.

6. Doumas BT, Perry BW, Sasse EA, Straumfjord JV Jr. Standardization in bilirubin assays: evaluation of selected methods and stability of bilirubin solutions. ClinChem 1973;19:984-93.

7. Peters T Jr, Biomonte JT, Doumas BT. Protein (total proteins) in serum, urine and cerebrospinal fluid. In: Faulknor WR, Muites S. Eds. Selected Methods in Clinical Chemistry. Washington DC: American Association of Clinical Chemistry. 1982; 9:510-2. 
8. Robertson WS. Optimizing determination of plasma albumin by the bromocresol green dye-binding method. ClinChem 1981;27:144-6.

9. Stromme JH, Eldjam L. Scandinavian standardization of enzyme determination. Scand J Clin Lab Invest 1974;33:287-9.

10. Bowers GN Jr, McComb RB. Measurement of total alkaline phosphatase activity in human serum. ClinChem 1975;21:1988-95.

11. Roberts NB. Alternative mechanized method for analysis for inorganic phosphate without reduction. ClinChem 1978;24:1836-7.

12. Munoz MA, Balon M, Fernandez C. Direct determination of inorganic phosphorus in serum with a single reagent. ClinChem 1983;29-372-4.

13. Territo MC, Tanaka KR. Hypophosphatemia in chronic alcoholism. Arch Intern Med 1974;134:445-7.

14. Dawson DJ, Babbs C, Warnes TW, Neary RH. Hypophosphatemia in acute liver failure. Br Med J (Clin Res Ed) 1987;295:1312-3.

15. Knochel JP. Does hypophosphatemia play a role in acute liver failure? Hepatology 1989;9:504-5.

16. Nanji AA, Anderson FH. Acute liver failure: a possible consequence of severe hypophosphatemia. J ClinGastroenterol 1985;7:338-40.

17. Rajan KS, Levinson R, Luvy CM. Hepatic hypoxia secondary to hypophosphatemia. Clin Res 1973;21:521-35.

18. Gundersen K, Bradley RF, Marble A. Serum phosphorus and potassium levels after intravenous administration of glucose: their use as diagnostic aids in diabetic and nondiabetic subjects with and without liver disease. N Engl J Med 1954;250:547-54.

19. Hayek ME, Eisenberg PG. Severe hypophosphatemia following the institution of enteral feeding. Arch Surg 1989;124:1325-8.

20. Matter BJ, Worona M, Donat P, Smith WO, Ginn HE. The effect of ethanol on phosphate excretion in man. Clin Res 1964;12:255-7.

21. Flink EB. Mineral metabolism in alcoholism. In: Kissin B Geleitor H. Eds. The Biology of Alcoholism. New York: Plenum Publishers 1991;20-38.

22. Strauss NB, Rosenbaum JD, Nelson WP III. The effect of alcohol on the renal excretion of water and electrolytes. J Clin Invest 1950;29:1053-8.

23. Nicholson WM, Taylor HM. The effect of alcohol on the water and electrolyte balance in man. J Clin Invest 1938;17:279-85.

24. Ylikahri RH, Poso AR, Huttunen MO, Hillborn ME. Alcohol intoxication and hangover: effects on plasma electrolyte concentrations and acid-base balance. Scand J Clin Lab Invest 1974;34:327-36.

25. Haldane JBS, Wigglesworth DB, Woodrow CE. The effect of reaction changes in human inorganic metabolism. Proc R Soc B 1924; 96:1-28. 
ORIGINAL ARTICLE

\begin{tabular}{|c|c|c|c|c|c|c|}
\hline & $\begin{array}{l}\text { Phosphate } \\
\text { (Mean } \pm \text { S.D.) }\end{array}$ & $\begin{array}{l}\text { Total } \\
\text { bilirubin } \\
\text { (Mean+S.D.) }\end{array}$ & $\begin{array}{l}\text { Total } \\
\text { protein } \\
\text { (Mean } \pm \text { S.D.) }\end{array}$ & $\begin{array}{l}\text { ALT } \\
\text { (Mean+S.D.) }\end{array}$ & $\begin{array}{l}\text { AST } \\
\text { (Mean+S.D.) }\end{array}$ & $\begin{array}{l}\text { A/G ratio } \\
\text { (Mean+S.D.) }\end{array}$ \\
\hline $\begin{array}{l}\text { Acute } \\
\text { liver } \\
\text { disease } \\
\text { group }\end{array}$ & $\begin{array}{l}3.22 \pm 0.57 \\
\mathrm{mg} / \mathrm{dl}\end{array}$ & $\begin{array}{l}5.44 \pm 4.26 \\
\mathrm{mg} / \mathrm{dl}\end{array}$ & $\begin{array}{l}7.55 \pm 1.25 \\
\mathrm{gm} / \mathrm{dl}\end{array}$ & $\begin{array}{l}238.12 \pm 19.39 \\
\text { IU/L }\end{array}$ & $\begin{array}{l}156.60 \pm 27.45 \\
\text { IU/L }\end{array}$ & $1.02 \pm 0.28$ \\
\hline $\begin{array}{l}\text { Chronic } \\
\text { liver } \\
\text { disease } \\
\text { group }\end{array}$ & $\begin{array}{l}3.36 \pm 0.54 \\
\mathrm{mg} / \mathrm{dl}\end{array}$ & $\begin{array}{l}4.99 \pm 3.72 \\
\mathrm{mg} / \mathrm{dl}\end{array}$ & $\begin{array}{l}7.23 \pm 0.92 \\
\mathrm{gm} / \mathrm{dl}\end{array}$ & $\begin{array}{l}98.96 \pm 10.42 \\
\mathrm{IU} / \mathrm{L}\end{array}$ & $\begin{array}{l}\text { 114.88+10.01 } \\
\text { IU/L }\end{array}$ & $0.97 \pm 0.33$ \\
\hline $\begin{array}{l}\text { Control } \\
\text { group }\end{array}$ & $\begin{array}{l}6.26 \pm 2.07 \\
\mathrm{mg} / \mathrm{dl}\end{array}$ & $\begin{array}{l}0.57 \pm 0.32 \\
\mathrm{mg} / \mathrm{dl}\end{array}$ & $\begin{array}{l}7.91 \pm 1.58 \\
\mathrm{gm} / \mathrm{dl}\end{array}$ & $\begin{array}{l}30.24 \pm 26.86 \\
I U / L\end{array}$ & $\begin{array}{l}67.84 \pm 11.58 \\
\mathrm{IU} / \mathrm{L}\end{array}$ & $0.95 \pm 0.30$ \\
\hline
\end{tabular}

\begin{tabular}{|c|c|c|}
\hline GROUPS & AGE RANGE & MEAN +/- s.d. \\
\hline ACUTE LIVER DISEAES & $17-69 Y R S$ & $33.40+/-14.39$ \\
\hline CHRONIC LIVER DISEASES & $17-63 Y R S$ & $45.84+/-13.63$ \\
\hline CONTROL GROUP & $16-66 Y R S$ & $44.56+/-14.80$ \\
\hline \multicolumn{2}{|r}{ AGE DISTRIBUTION } \\
\hline
\end{tabular}

\begin{tabular}{|l|l|l|l|}
\hline \multicolumn{4}{|l|}{ PHOSPHATE } \\
\hline & Mean & \multicolumn{2}{|c|}{ Standard Deviation } \\
\hline Group 1 & 6.264 & 2.074 & \\
\hline Group 2 & 3.216 & 0.571 & \\
\hline
\end{tabular}

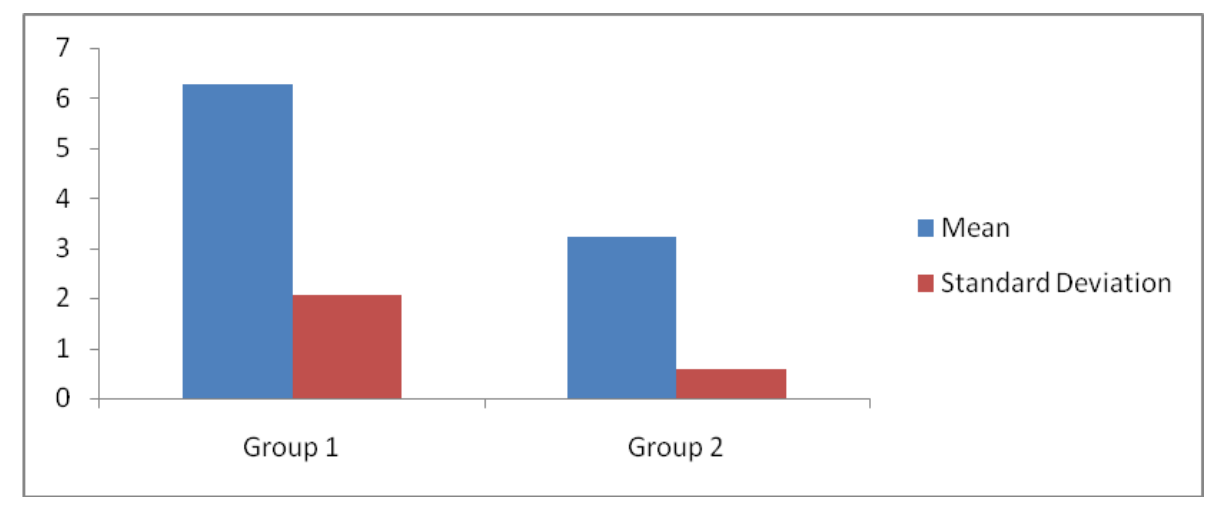




\section{ORIGINAL ARTICLE}
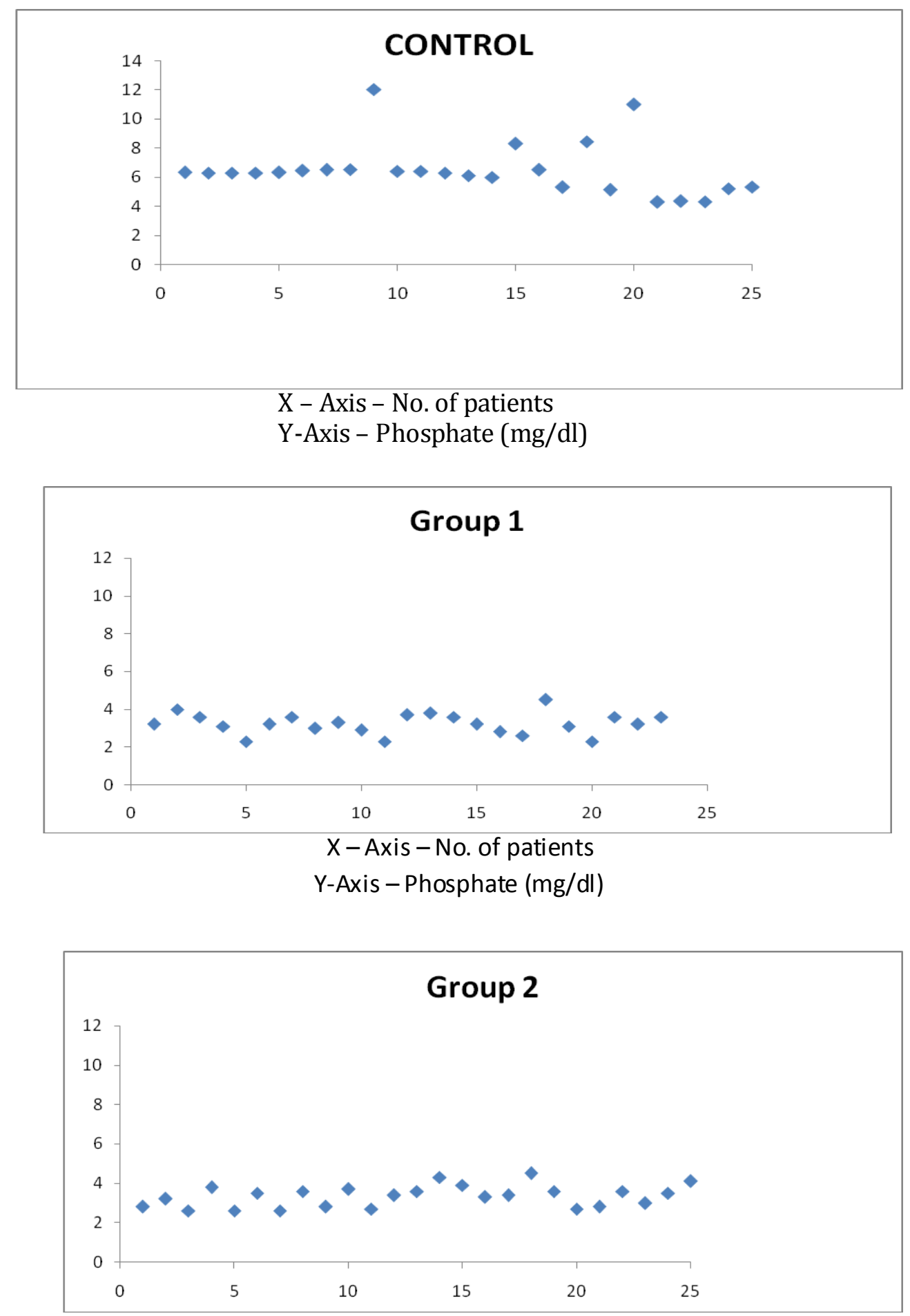


\section{AUTHORS:}

1. Pradeep. V. Vernekar ${ }^{1}$

\section{PARTICULARS OF CONTRIBUTORS:}

1. Associate Professor, Department of G eneral Medicine, Srinivas Ins titute Of Medical Sciences \& Research Centre Mukka, Surathkal, Mangalore.

\section{NAME ADDRESS EMAIL ID OF THE}

\section{CORRESPONDING AUTHOR:}

Dr. Pradeep. V. Vernekar.

Associate Professor of General Medicine.

Srinivas Institute of Medical Sciences \& Research

Centre Mukka, Surathkal, Mangalore.

Email - drpradeepvernekar@yahoo.com

Date of Submission: 03/10/2013.

Date of Peer Review: 04/10/2013.

Date of Acceptance: 21/10/2013.

Date of Publishing: 26/10/2013 